\title{
Belgeo
}

Revue belge de géographie

$1-2 \mid 2012$

Inaugural issue

\section{Social sciences and comparative research in Europe : cross-national and multi-disciplinary projects for urban development. The role of geography}

Sciences sociales et recherche comparative en Europe : projets transnationaux et projets multidisciplinaires de développement urbain. Le rôle de la géographie

\section{Armando Montanari}

\section{OpenEdition}

\section{Journals}

\section{Electronic version}

URL: http://journals.openedition.org/belgeo/6085

DOI: 10.4000/belgeo.6085

ISSN: 2294-9135

\section{Publisher:}

National Committee of Geography of Belgium, Société Royale Belge de Géographie

\section{Electronic reference}

Armando Montanari, «Social sciences and comparative research in Europe : cross-national and multidisciplinary projects for urban development. The role of geography », Belgeo [Online], 1-2 | 2012, Online since 15 December 2012, connection on 30 April 2019. URL : http://journals.openedition.org/ belgeo/6085; DOI : 10.4000/belgeo.6085

This text was automatically generated on 30 April 2019.

Belgeo est mis à disposition selon les termes de la licence Creative Commons Attribution 4.0 International. 


\section{Social sciences and comparative research in Europe : cross-national and multi-disciplinary projects for urban development. The role of geography $^{1}$}

Sciences sociales et recherche comparative en Europe : projets transnationaux et projets multidisciplinaires de développement urbain. Le rôle de la géographie

\section{Armando Montanari}

\section{Introduction}

1 The social sciences encompass disciplines focusing on society and on people as a part of society. The word "sociology" is a combination of the Latin word "socius" (companion) and the Greek "lógos" (word, knowledge). Anthropology, archaeology, criminology, economics, education, geography, history, international relations, law, linguistics, political sciences, psychology and sociology are generally considered social sciences in that they certainly do not make up the natural sciences. Among these is the specific case of geography, a discipline capable of understanding physical geography - predominantly a natural science - and other branches of geography, which mainly fall into the social sciences. The issue here is not to catalogue these fields at any price, but it does need to be emphasised that geographers - both physical and economic - often follow the same university syllabus and belong to the same professional organisations, and are all members of the International Geographical Union (IGU), which in its turn is a member of the International Social Science Council (ISSC) while also being a part of the International Council for Science (ICSU), which is made up of associations representing the fields of anthropology and psychology, but not the other social sciences. This paper examines the 
earliest comparative research projects coordinated by the ISSC and concludes with an examination of comparative analysis projects financed by the EU.

\section{The social sciences and comparative research}

UNESCO set up the ISSC in 1951 with the objective of encouraging cooperation among researchers in various fields. The idea was essentially to internationalise the social sciences and thereby help social science researchers all over the world to achieve concrete forms of cooperation such as exchanging information and verifying theories in different social and cultural contexts by comparing models, procedures and results. It was hoped that this process would overcome the barriers that had historically been drawn up between disciplines, and the even stronger barriers created by the differences between countries that had emerged in the course of the two world wars in the first half of the 20th century. UNESCO's definition of the social sciences as the science of society encompassed the fields of anthropology, archaeology, criminology, history, geography, law, political science and international relations, psychology, sociology and town planning.

In its earliest years of existence, the ISSC's internationalisation programme focused on two main activities. In 1962 it organised a number of meetings, seminars and workshops, and in 1963 it set up the European Centre for the Co-ordination of Research and Documentation in the Social Sciences (Vienna Centre) specifically to organise research projects involving researchers from both centrally planned and free market economies : in other words, Eastern and Western Europe. The early years of ISSC activity were devoted to promoting infrastructure for use by social scientists, such as data banks, libraries and data processing software. According to Szalai, Petrella et al. (1977), processing systems were applied to already available data. On the basis of research by other organisations in preceding decades, such as that of the Royal Anthropological Society at the end of the 19th century, problems of data collection and comparability were disregarded, as it was not easy to influence the many national authorities in charge of data collection. These authorities worked using methods based on radically different economic and social situations and cultures. What was far more important was the ISSC's support of research based on direct interviews, as the interview technique had not been sufficiently developed in the social sciences until then.

UNESCO had already attempted to internationalise this kind of research in 1948 with its project to carry out a survey in nine countries : Australia, Britain, France, West Germany, Italy, The Netherlands, Norway, Mexico and the USA. Around a thousand respondents were surveyed in each of the nine countries using a common questionnaire with 21 questions divided into five themes. The results of the survey were published in a book by Buchanan and Cantril (1953). The five themes were: 1. the individual's estimate of his own position in the class structure of his country and its relation to his attitude toward other people at home and abroad;2. the individual's feeling of personal security in matters unrelated to international affairs and his satisfaction with life in his own country as compared with how he might live in some other country ; 3 . the individual's feeling of friendliness for the people of some countries and unfriendliness for those of others; 4 . the individual's stereotypes about the character of his own countrymen and various foreign people ; 5 . the individual's ideas about human nature (can it be changed ?), world government (is it possible?), and peace. All the questions were drawn up by American 
researchers, and researchers in the concerned countries merely asked the questions. Up until the 1960s, research of this type was dominated by American academics, as the US was the only country where sufficient research funding could be obtained. This has been described as "data imperialism". Buchanan and Cantril (1953) analysed the results obtained in two ways, by response type and by country. For example, in their summary of results on country stereotypes, Buchanan and Cantril state (1953, p. 57): (i) that there exists a tendency to ascribe certain characteristics to certain people; (ii) that respondents of all countries tend to describe Russians in the same terms, but show somewhat less agreement on the Americans ; (iii) that stereotypes of one's own country are invariably flattering; (iv) that the prevalence of complimentary over derogatory terms in a national stereotype is a good index of friendliness between nations. Without referring specifically to the results of this study, Szalai, Petrella et al. (1977, p. ix) write : “... this procedure clearly produced a variety of distortions : too many of the questions were phrased and too much of the analysis was carried out in ignorance of the cultural intricacies and socio-political realities of each of the systems covered...". Szalai (1966) used the term "safari-type" to define this kind of cross-national survey, referring sarcastically to a researcher with sufficient funding who goes to the country he is researching - where he can count on the assistance of the best local guides - after preparing his survey in a few short weeks using his culturally and technologically advanced instruments; he then sends the data collected in the field back home. After a few expeditions of this kind, he finally returns to his university to process the data with his team, and ends up convinced he has a better understanding than "native" researchers of some aspects of social and cultural life in those faraway countries. These considerations led to a marked change in the 1960s. In 1963 the ISSC decided to "Europeanise" cross-national research, and set up the Vienna Centre that same year for the purpose.

\section{The role of the Vienna Centre and the figure of Adam Schaff}

5 One of the main players in the management and continuity of the Vienna Centre was Polish philosopher Adam Schaff (1913-2006), a key figure of contemporary European culture. In a conversation with A. Ponzio (2002, p. 242), Schaff recalls : “... in Poland, the year 1968 was marked by an acute phase of Communist-Fascist feeling, with strong demonstrations of anti-Semitism. My personal safety was in great danger... I escaped because of Gomulka's affection for me ; he did not allow the Communist-Fascists to carry out the plans they had for me, and granted me a honourable exile in Vienna...". Schaff was awarded an honorary degree by Princeton University and later became an honorary professor at the University of Vienna. Austrian law entitled him to obtain citizenship; however, this would have meant the loss of his Polish citizenship. Schaff says: "Once again, I chose Poland... in Vienna, I became president of the Vienna Centre, a post I held for 20 years. The Centre played a leading role in the development of scientific and cultural relationships between Eastern and Western Europe...". Having worked from 1979 to 1983 as scientific secretary of the Vienna Centre, the author of this paper is in a position to sum up a few significant elements of those years. Schaff said in his conversation with A. Ponzio (2002, p. 79) that reality is continuously "moving and being transformed, but its elements experience relatively balanced states. Hence the duplicate 
objective image of reality and the duality of the laws governing it ; reality is both dynamic and static, mobile and (relatively) immobile, and is hence governed by (casual) dynamic and (coexistential, morphological) synchronic laws..." Only complementary analysis, in which doubt anticipates certainty, can make a substantial contribution to knowledge, despite the complications this process implies. In the historical process, synchronic research follows diachronic research and vice versa, in an alternating combined system. In the same interview (Ponzio, 2002, pg. 81), Schaff points out: “...this does not mean that one of the two methods of study permanently eliminates the other, alternative one; on the contrary, it means that in the dialectical alternation of thesis and antithesis, according to Hegel's classic model, the two methods prepare the basis for a new synthesis, for knowledge of the world to progress anew..." During his first decade as president of the Vienna Centre, Schaff was heavily involved in supporting the work of the Final Act of the 1975 Helsinki Conference, and subsequently promoted a series of meetings devoted to analysing the Helsinki Final Act from a semiotic point of view (Villain-Gandossi, 1989).

6 From the end of the 1970s onwards, Schaff devoted his thinking to the new possible forms of employment that would be required to adapt to innovations deriving from the introduction of Information and Communication Technology in the production sector. He involved the Vienna Centre in this thought process, notably with a project titled "Socioeconomic problems and potentialities of the application of micro-electronics at work", the results of which were published in books by Berting, Mills and Wintersberger (1980), Grooting (1986) and Grooting, Gustavsen and Héthy (1989). In those years, he stated on more than one occasion that the idea of the automation of products and services leading to the "end of employment" could only refer to a specific form of traditional work, salaried employment, not employment as a whole. People have done various jobs in the course of thousands of years of human history, but it is only during the relatively short time span of the capitalist social order that people have worked for a salary. The future Schaff outlined was made up of questions rather than answers, and inspiration rather than assertions. He was undoubtedly also referring to a continuously evolving society, and hence the need for "lifetime study" as a way to continuously and broadly complete knowledge. In this way several opportunities for new occupations could be created, which in their turn would in any case create new problems for society. Schaff (1982) published these reflections in the context of active collaboration with Aurelio Peccei and the Club of Rome - quite a significant collaboration, as until then the Club of Rome had met with opposition in the Eastern European countries. It also led to the start of the Turin Project International (Grundmann, Lever et al., 1989) in collaboration with national working groups coordinated by the municipalities of Turin, Cologne, Krakow, Dresden and Glasgow - an attempt to shake up the relationship between research institutes and municipalities and bring research results closer to end users. The experiences of the ISSC and subsequently the Vienna Centre in the field of comparative research were extremely innovative. By 1980, 23 countries had become members of the Vienna Centre: Austria (the Federal Ministry for Science and Research), Belgium (the Ministry for Culture), Bulgaria (the Bulgarian Academy of Sciences), Czechoslovakia (the Czechoslovak Academy of Sciences), Denmark (the Danish Social Science Research Council), Finland (the Ministry of Education), France (the Ministry of Foreign Affairs), the German Democratic Republic (the Academy of Sciences of the G.D.R.), the Federal Republic of Germany (the Federal Ministry for Research and Technology), Great Britain (the Social Science Research 
Council), Greece (the Ministry of Coordination), Hungary (the Hungarian Academy of Sciences), Italy (the National Research Council), The Netherlands (the Ministry of Education and Sciences), Norway (the Norwegian Research Council for Science and Humanities), Poland (the Polish Academy of Sciences), Romania (the Romanian Academy of Social and Political Sciences), Spain (the Spanish National Commission for UNESCO), Sweden (the Swedish Council for Research in the Humanities and Social Sciences), the U.S.S.R (the Academy of Sciences of the U.S.S.R.) and Yugoslavia (the Croatian Research Community).

\section{The problems of promoting and managing comparative research}

7 The news of the spread of comparative research in the social sciences undoubtedly sparked a great deal of enthusiasm. At the same time, however, the growing participation of researchers emphasised a number of problems and limitations. The ISSC and the Vienna Centre therefore agreed to verify results by comparing the projects with similar projects that were underway in the USA on the occasion of a conference in Budapest in July 1972 (Szalai and Petrella, 1977). The first International Seminar on Cross-National Comparative Research in Warsaw in September 1980 (Niessen and Peschar, 1982) offered a further opportunity for reflection on the subject. Schaff (1982) pointed out that the initiative was in line with the conclusions of the Scientific Forum of the Conference on Security and Co-operation in Europe, held in Hamburg in 1980, which stated that "... appropriate support should be given to arrange advanced seminars and training courses for young scientists from participating and other States that would enable them to study new scientific methods for shorter or longer periods. Information about these activities and arrangements should be disseminated as widely as possible...". The projects coordinated by the Vienna Centre (Kourilsky, Montanari, Vyskovsky, 1980) were carried out in these phases: (i) Preparation of the proposal to be revised by the Vienna Centre Programme Committee and preliminary contacts with potential participants; (ii) Drawing up the methodological approach and identifying the reference concepts; (iii) Data collection and field work in the participating countries; (iv) Data processing and comparative analysis; (v) Preparation of common publications : writing, revising and editing text ; (vi) Publication : sending the manuscript to the publisher.

8 A list of problems can be drawn up from this procedure. The first concerns the reasons for comparative research: why undertake a cross-national comparative study? To answer this question, other questions must be taken into account: what to compare? How to compare? What should be examined to carry out comparative analysis ? Berting (1982) notes that international comparative studies in the social sciences generally require bigger budgets and greater commitment than studies carried out exclusively at a national level. He explains that apart from the financial cost, one must not underestimate the duration of the project, the loss of the individual researcher's scientific independence and the costs of coordinating research groups and individual researchers. These costs contribute to making up a further cost represented by what Berting calls "tension management" : the skills and energy required to manage the coordination. Hence, so as not to experience bitter disappointment, cross-national comparative studies must ensure a yield, an added value, to compensate for the higher costs. Until the end of the 1980s, reference was also made to another benefit: being able to contribute to cooperation 
among researchers and different cultures and traditions, better international understanding and hence peace. Berting (1982) tackles the issue of finding a rule to identify the level of internationalisation of research using four parameters : conception, data collection, analysis and interpretation (table 1). On the basis of the projects considered, he used ( $\mathrm{N}$ ) to identify mainly national situations and (I) for mainly international situations. While all these projects were called international in social sciences literature because the research topic was international, the fact that at least one or more of the parameters taken into consideration had a prevalently national character should have given them a different typological definition. Reflections of this kind have contributed to greater clarity for the researchers involved in projects and the methods used.

Table 1. Cross-national research : levels of internationalisation.

\begin{tabular}{|l|l|l|l|l|l|l|}
\hline Types & I & II & III & IV & \multicolumn{2}{l|}{ V VI } \\
\hline Criteria & $\begin{array}{l}\text { National } \\
\text { research into } \\
\text { several states }\end{array}$ & $\begin{array}{l}\text { "Imperialist" } \\
\text { research }\end{array}$ & $\begin{array}{l}\text { "Respeated" } \\
\text { research }\end{array}$ & $\begin{array}{l}\text { Regressive } \\
\text { research }\end{array}$ & \multicolumn{2}{l|}{$\begin{array}{l}\text { Cooperative } \\
\text { research }\end{array}$} \\
\hline Conception & N & N & N & I & I & I \\
\hline $\begin{array}{l}\text { Data } \\
\text { Collection }\end{array}$ & N & I & I & I & I & I \\
\hline Analysis & N & N & I & N & I & I \\
\hline Interpretation & N & N & N & N & N & I \\
\hline
\end{tabular}

$(\mathrm{N}=$ national $; \mathrm{I}$ = international)

Source : Berting (1982, p. 11)

Pickvance (2001) points out that comparative analysis is not equivalent to analysis. The two actions do not coincide in any way ; the first is a sub-category of the second. When we consider comparative analysis, we should take into account the fact that it must envisage data collection in two or more case studies. The size of the case studies, be they countries, cities, companies or households, is irrelevant. A second condition is that the objective of the research must be to explain rather than analyse phenomena. Hantrais and Mangen (1996) note that when researchers from different fields and cultures come together to collaborate on an international project, they can establish important personal contacts that allow them to enhance their ability to understand and interpret a significantly larger variety of conceptual approaches. Comparative analysis also makes it possible to delve deeper into key themes in other societies. In this way, differences and issues that an individual researcher would be unable to pick up on can also be better developed. Finally, researchers engaged in comparative analysis are obliged to adopt a different cultural perspective that leads them to understand the processes of another country through the viewpoint of people living and working in that country, and hence to subsequently review the problems of their own country from an external perspective. Over the past few decades, participation in cross-national research projects has also been considered in the 
light of the mobility of the researchers. The interest in this phenomenon is justified by the fact that it entails a significant increase in the exchange of information and knowledge, and hence of related phenomena of innovation. Innovation means a greater capacity to enter international markets, increased growth and therefore more jobs. This need, initially expressed by multinational companies, has since been adopted by European governments and included in a 2000 plan known as the Lisbon Strategy. To overcome the operational difficulties that delayed the implementation of the strategy, the EU then drew up a renewed Lisbon Strategy agenda for the 2008-2010 period amid the effects of an international economic crisis that has still not been resolved. The key objectives of this new document included the following two aims: "investing in knowledge" to help create a "fifth freedom" in Europe - the free movement of knowledge, and creating a European research area with improved conditions for scientific innovation. Cross-national research must also be considered in perspective, and with regard to its ability to encourage the exchange of researchers and international cultural experiences beyond the conclusions of a given project. Lynn (2003) points out the need to develop standards for survey design and implementation, which are particularly important for international research. He proposes five approaches. These are not new methods as such, merely a body of thought that is necessary for the choice of methods. Wiatr (1977) states that cross-national analysis projects do not necessarily need to be targeted at formulating, verifying or modifying methodological hypotheses. They can also describe models of differences and similarities in the various circumstances studied. In this case the projects can be said to have a "descriptive" objective. This definition does not exclude the possibility of using the results of the research study. So the objectives can represent a continuum between a "descriptive" and a "theoretical" phase. Also, the strategies relating to the composition of the group, the choice of case studies and the organisation of the research can be "pragmatic" or "theoretical". According to Wiatr (1977), typologies (A) and (D) make up the dichotomy of "a-theoretical"-"theoretical" studies, while typologies (B) and (C) indicate that theoretical considerations play a nondominant role (table 2).

Table 2. Strategies and objectives in Cross National Researches.

\begin{tabular}{|l|l|l|l|}
\hline \multirow{2}{*}{} & \multicolumn{3}{|l|}{ OBJECTIVES } \\
\cline { 2 - 4 } & & descriptive & theoretical \\
\hline \multirow{3}{*}{ STRATEGIES } & Pragmatic & (A) & (B) \\
\cline { 2 - 4 } & Theoretical & (C) & (D) \\
\hline
\end{tabular}

Source : Wiatr (1977, p. 357)

Berting (1982) proposes a distinction between discipline-oriented and policy-oriented research. In the first case the project's reference is a problem within one of the social science disciplines that is placed at the centre of the project. In the second case the project acquires as its objective the analysis and, if possible, the solution of a problem expressed by society through its stakeholders. The combination of these two analysis criteria results in four different research types. (a) indicates projects starting from a 
disciplinary perspective to explain phenomena of importance to society ; (b) indicates projects that include the study of policy measures, the elucidation of policy problems and the evaluation of the effects of policy ; (c) ideographic and exploration research projects ; (d) collection and elaboration of data that are primarily useful for policy makers and stakeholders (table 3).

Table 3. Discipline oriented and policy oriented research projects.

\begin{tabular}{|l|l|l|}
\hline & Discipline oriented & Policy oriented \\
\hline theoretical & (a) & (b) \\
\hline descriptive & (c) & (d) \\
\hline
\end{tabular}

Source : based on Berting (1982)

\section{The Vienna Centre : Cross-national research and urban development}

11 Robinson (1969) recalls that, from its inception, the Board of Directors of the Vienna Centre had pointed out the need to promote research on subjects that the main national research institutes were already looking into. The subject identified was "Backward Areas", and a dozen European research institutes began to work on it together from 1963. In 1967 they finally decided to organise a conference, together with the International Economic Association, in Varenna (Italy). The conference was attended by researchers from Austria (University of Vienna), Belgium (University of Liège), Bulgaria (Academy of Sciences), Czechoslovakia (Academy of Sciences), France (University of Paris), Italy (S. Cuore Catholic University), the Netherlands (University of Utrecht), Poland (University of Wroclaw), Sweden (University of Umeå), the UK (University of Cambridge), Yugoslavia (University of Belgrade) and the US (Brown University, Rhode Island). The presence of such a large number of research groups confirmed that the subject of backward areas was quite widespread, and hence studied, in both northern and southern countries, with centrally planned as well as free market economies. The theoretical basis for the project was the relationship between a city, or its conurbation, with the region to which it belongs and with the rest of the economy of which it is part. The concept devised by Von Thünen (1966) around the mid-19th century was used as the model, together with the subsequent contribution by Isard (1956) ; on the basis of these theories, “... if the city and its associated region are to be in equilibrium with the remainder of the economy and the world outside the economy, there must be exports of goods or services from the city and its associated region equivalent to the imports, save..." (Robinson, 1969, p. 16). In 1964 the Vienna Centre launched the project "Les régions en retard des pays industrialisés". The results of the project were published in books by Petrella (1971), Pötzsch and Voigt (1972) and Kuklinski and Petrella (1972). The scientific debate within the Vienna Centre project brought to light, among other things, that a natural trend of development and growth was facilitated above all by amenities being more easily available in cities, which have a more variegated economic structure and offer greater and better-quality social services. Klassen (1972, p. 36) states: “... for the present we are only interested in the advantages 
of cities over rural areas, without being too romantic about rural life or too pessimistic about the social problems created by very large cities...". In the same chapter Klassen (1972) recalls the diseconomies of scale in big cities, which are also often faced with social costs that medium-sized towns do not have. In big cities, moreover, congestion in urban cores, social problems in old districts and criminality are also significantly higher. To be able to function, big cities need high levels of motorisation that produce serious air pollution, adding to industrial pollution. Water pollution is also high, and as a result big cities are becoming less attractive and unfit for habitation. Everything possible should be done to limit their growth. Those involved in the project therefore began to discuss what should be the optimal size of an urban structure that would also be able to tackle the problems of air and water pollution. On the basis of these considerations, participants in the "Backward regions in industrialised countries" project decided to propose a new project on the problems of urbanisation. In 1971, Gaston Gaudard and Jean Valarché of the University of Fribourg presented a proposal to the Board of Directors of the Vienna Centre on this subject. The project, called "The Costs of Urban Growth" (CURB), got underway in 1973 and involved research groups from Austria, Belgium, Bulgaria, Denmark, France, the Federal Republic of Germany, Hungary, Italy, the Netherlands, Poland, Sweden, Switzerland, the UK and Yugoslavia. The feasibility phase was completed in 1973-1974, the first phase of the project in 1975-78 and the second phase in 1979-82, with the publication of the results (Van den Berg, Drewett, Klassen, Rossi, Vijverberg, 1982). During the same period, the work of geographer Brian Berry (1973) at Harvard University had shown how civil societies differ in their planning capabilities. These cultural differences have produced divergent aims and different planning methods, and have therefore contributed to the spread of urbanisation and counter-urbanisation. The urbanisation phenomenon can be fully understood only in the context of the wide spectrum of interrelated cultural processes. Subsequently, Berry (1976) wrote that there had been a radical change in the 1960s in the urban experience in the US. Counterurbanisation had replaced urbanisation as the dominant process of settlement in the country, thereby reaffirming a basic predisposition of American culture, which is naturally incompatible with urban concentration. Berry was part of the ISSC and the International Geographic Union (IGU), and therefore referred in his book to studies carried out in various countries including the US, the UK, the USSR, Australia, Canada, Africa, Brazil and China. Roy Drewett (1976), the author of the chapter on the UK, also participated in the CURB project and coordinated it from the outset. Berry (1976) explains that his book illustrates differences and conflicts. Countries with a free market economy consider the growth of big cities to be inevitable and proportional to economic success; these cities therefore grow and simultaneously disintegrate under the impulsion of individual interests. In societies with free market economies, alternative models for urban growth are being proposed, while the destruction of old city centres is being abandoned. Conflict developed in the context of the different cultures, but also between Berry, who believed in the modelling of phenomena and the ISSC and IGU, which had traditionally contested this cultural approach. These differences can also be seen within the CURB project : they delayed its management and execution (Montanari 2012a, 2012b). Many of the CURB project participants subsequently worked together again in the "Innovation and urban development: the role of social and technological change" (URBINNO) project co-ordinated by the European Centre for Social Welfare Training and Research in Vienna (1987-90), which produced books by Nijkamp (1990), Strohmeier and Matthiessen (1992) and Montanari, Curdes and Forsyth. This was then followed by the 
"Regional and Urban Restructuring in Europe (RURE)" project co-ordinated by the European Science Foundation (ESF) in Strasbourg (1988-93), which produced twenty-odd books, as Malberg (1996) notes. In all these projects, there is a continuity of institutes and people over a few decades. Among the researchers are U.Schubert (Austria), P. Popov (Bulgaria), C.Matthiessen (Denmark), C.Lacour (France), L.H.Klaassen (The Netherlands), G.Gaudard (Switzerland) and V.B.Music (Yugoslavia). Francesco Vito, Rector of the Catholic University of Milan, was Italy's representative at the 1967 meeting. Vito, who had considerable experience of international co-operation, died unexpectedly on 6 April 1968 , but continuity of presence was guaranteed by the subsequent research projects by his students O.Garavello and L.Frey, and then by A.Caloia and L.Senn starting from the CURB project.

\section{Urban development : The $\mathbf{G}$ factor in cross-national research}

The 1970-2000 period registered an increasing involvement of geographers and geography in comparative analysis projects on urban development. Meanwhile, another two phenomena had occurred that enhanced geographers' ability to participate. The first was the growth in the quantity and complexity of available data. The second was the introduction of a new ICT instrument, the Geographic Information System (GIS). The GIS helps research in two ways: the organisation of data, and data processing capable of covering any knowledge lacunae. When regional economists involved in early projects coordinated by the Vienna Centre began to refer to the concept of the metropolitan area and classify economic and social phenomena as "core" and "ring" they opened up collaboration with geography. Subsequently, when urban themes began to be increasingly concerned with atmospheric pollution and the management of natural resources, the number of disciplines involved in research increased significantly, while geography was able to continue to carry out its central role and also draw on the skills of physical geography. However, the selection, collection and processing of geographical data, both qualitative and quantitative, became increasingly onerous. All human activity and decisions have long presupposed a significant geographical component that, through the use of mobile phones and GPS, concerns us all. Geography has always been involved in understanding the world and studying the role of human beings in their evolution. For this reason, geography more than other disciplines has had a long tradition of study in spatial analysis, and greater familiarity with the spatial management and perspectives of research. Haggett (2001) classes the problems involved into four categories: (i) the quantity of available geographical data has increased exponentially. Today, a satellite can, in a few minutes, collect and transmit to Earth a quantity of data that a few decades ago we would only have been able to collect over several years of work ; (ii) the quantity of data collected presupposes a considerable variety and quality of georeferencing. While some data refer to specific places, others cannot be georeferenced as precisely. The need to work simultaneously on different types involves substantial efforts; (iii) in this situation the quality of data is not equally guaranteed and hence there is a risk of the results proposed being imprecise ; (iv) the internationalisation of data and the possibility of exchanging them continuously is not always compatible with their selection method.

13 The existence of a "G Factor" is due to the fact that while geography as a discipline plays a fundamental role in the new activities of comparative research, geographers do not 
seem adequately equipped for it. Ronald Abler (1988), President of the IGU (2008-2012), maintained that, for geography, the GIS would be a technological revolution on par with the microscope, the telescope and the computer for medicine, biology and the natural sciences."... It... could therefore be the catalyst needed to dissolve the regional-systematic and human-physical dichotomies that have long plagued geography..." (Abler, 1988). He went so far as to hope for a new culture of geography that could resolve the field's conflicts and dichotomies. It is unsure whether he is still convinced of this phrase, but things have undoubtedly moved to some extent in the direction of Ron Abler's hopes. Many of the solutions proposed by geographers to the problems of managing geographical and GIS data derive from the experiences of the so-called "quantitative revolution" of geography in the 1960s, which had the effect of spreading the quantitative approach among geographers. British geographer Stewart Fotheringham can be credited with collating this experience and describing methods and techniques to understand the nature of weighted spatial regression (Fotheringham A.S., Brundsdon Ch. and Charlton M., 2000 and 2002). Abler (1993) is also very critical of geographers, whom he accuses of often being engaged in caricaturing geography; he intentionally uses the word "caricature", referring to the meaning of the word in Webster's dictionary as "exaggeration by means of deliberate and sometimes even grotesque distortion of parts or characteristics".

\section{Cross-national research and urban development starting from the European Commission's FP7 projects}

14 The FP7 projects have been selected because this programme best interprets the EU's Lisbon Strategy, which identifies knowledge as the element to transform the EU countries into the most dynamic world markets. Knowledge is based on three inter-connected elements : research, education and innovation. The EC has divided the FP7 programme projects into four categories: Cooperation, People, Ideas and Capacities. "Cooperation" promotes comparative analysis research based on trans-national cooperation, and its objective is to acquire or consolidate leadership in research in key sectors and technological areas. Projects in the "Cooperation" category are based on networks of researchers working in different countries either within or outside the EU, depending on the type of call for proposals. These calls for proposals select projects that are all of good scientific quality, have international collaboration as a prerequisite and, for many of the projects, involve not only researchers but also companies as partners, stakeholders or end users. Each project proposal is the result of an international knowledge network that structures itself properly once the project enters its operational phase, and continues to some extent even after the project is over. 
Table 4. ENV urban research FP5-FP6-FP7.

\begin{tabular}{|l|l|l|l|l|}
\hline & Total & FP5 & FP6 & FP7 \\
\hline Projects & 153 & 110 & 22 & 21 \\
\hline Costs & $€ 382 \mathrm{ml}$ & $€ 202 \mathrm{ml}$ & $€ 78 \mathrm{ml}$ & $€ 102 \mathrm{ml}$ \\
\hline
\end{tabular}

SOURCE : AUTHOR'S CALCULATION BASED ON A EUROPEAN COMMISSION RELEASE last three FP in the ENV (environment) sector, taking into consideration FP7 figures as of January 2010. The project themes were pollution management (n.30), planning (n.39), urban structures and services (n.28) and natural resources (n.32). A study on the CORDIS website in April 2012 on projects focusing on urban settlements notes that there are 18 projects underway following calls for proposals in the ENV, SSH and ICT sectors. Other projects besides these were also underway following calls for proposals in the ERC and PEOPLE sectors. The 18 above-mentioned projects have been singled out here because they entail the presence of a multi-disciplinary and cross-national network of researchers in line with the objectives of this paper. The biggest projects, with a cost of around $€$ 8-9 million, are only four in number - two ENV and two ICT calls for proposals. The subjects are information and media, regional and sustainable development, energy storage and transport, and environmental protection. The projects are being coordinated by an Austrian, Italian, Belgian and Irish group respectively. All in all, 18 research groups from 22 EU countries, other European countries (Croatia, Norway, Serbia, Switzerland and Ukraine) as well as Brazil, India, Israel, Peru, South Africa, Turkey, the US and Vietnam are participating in these projects.

\section{Conclusions}

Cross-national, multi-disciplinary comparative research is a key element for the spread of knowledge and information, and hence innovation. The EU is well aware of this, and is therefore investing substantial funds each year to finance research in Europe. The recent history of comparative research in the social sciences has been reconstructed in this paper to explain that it is a complex process in which we must believe, and to which we must all devote our best efforts. In these years of economic crisis, funding sources for research have practically dried up at the national level. What remains are the possibilities offered by the EU's long-term research programmes. Setting up a cross-national, multidisciplinary research group is not a simple task, and cannot be completed within a few days or a few weeks. The preparation of a competitive multi-disciplinary project is equally complex, because the underlying demands of European society must be understood for each subject, while introducing elements of innovation in the various disciplines involved in the research project. As a result, there is a need for preparation and continuity of action in this field by individuals and above all by institutes. Universities and research institutions must therefore encourage international and multidisciplinary cooperation in every way by including this component in their syllabus. If it is to be successful, this long-term commitment requires dedication and sacrifices that 
must be given sufficient consideration in the advancement of individual careers and the evaluations of research organisations.

\section{BIBLIOGRAPHY}

ABLER R.F. (1988), “Awards, rewards and excellences : keeping geography alive and well”, The Professional Geographer, 40, pp. 135-140.

ABLER R.F. (1993), "Everything in its place : GPS, GIS and geography in the 1990s", The Professional Geographer, 45, pp. 131-139.

BERRY B.J.L. (1973), The human consequences of urbanisation, London, Macmillan.

BERRY B.J.L. (ed.) (1976), Urbanisation and Counterurbanisation, London, Sage Publications.

BERTING J. (1982), "Why compare in international research ? Theoretical and pratical limitations of international research" in NIESSEN M. and PESCHAR J. (eds.) (1982), International Comparative Research. Problems of theory, methodology and organisation in Estern and Western Europe, Oxford, Pergamon Press, pp. 5-16.

BERTING J., MILLS S., WINTERSBERGER H. (eds.) (1980), The Socio-Economic Impact of Microelectronics : International Conference on Socio-Economic Problems and Potentialities of Microelectronics, Sept. 1979, Zandvoort, Netherlands, Oxford, Pergamon Press.

BUCHANAN W., CANTRIL, H. (1953), How Nations See Each Other, Urbana, The University of Illinois Press.

DREWETT R., GODDARD J., SPENCE N. (1976), “Urban Britain : beyond containment”, in BERRY B.J.L. (ed.), Urbanisation and Counterurbanisation, London, Sage Publications, pp. 43-79.

FOTHERINGHAM A.S., BRUNSDON C., CHARLTON M. (2000), Quantitative geography : perspectives on spatial data analysis, London, Sage.

FOTHERINGHAM A.S., BRUNSDON C., CHARLTON M. (2002), Geographically weighted regression : the analysis of spatially varyng relationships, Chichester, John Wiley \& Sons.

GROOTINGS P. (ed.) (1986), Technology and work : East- West comparison, London, Croom Helm. GROOTINGS P., GUSTAVSEN B., HÉTHY L. (1989), New form of work organisation in Europe, New Brunswick, N.J., Transaction Publishers.

GRUNDMANN S., LEVER W.F. with VILLAIN-GANDOSSI C. (eds.) (1989), Social and Economic Changes in Metropolitan Areas: Problems and Experiences of the Participant Cities of Project Turin International, Vienna, International Social Science Council, European Coordination Centre for Research and Documentation in Social Sciences.

HAGGET P. (2001), Geography : a global syntesis, Harlow, Pearson Education.

ISARD W. (1960), Methods of Regional Analysis ; an Introduction to Regional Science, New York, Wiley.

KLASSEN L.H. (1972), "Growth poles in economic theory and policy" in KUKLINSKI A. and PETRELLA R. (eds.), Growth poles and regional policies, The Hague, Mouton, pp. 1-43. 
KOURILSKY C., MONTANARI A., VYSKOVSKY G. (eds) (1980), Vienna Centre Report of Activity 1979-80, n.10 \& 11, pp. 1-44.

KUKLINSKI A. \& PETRELLA R. (eds.) (1972), Growth poles and regional policies, The Hague, Mouton.

LYNN P. (2003), "Developing quality standards for cross- national survey research : five approaches”, International Journal of Social Research Methodology, 6, 4, pp. 323-336.

MALBERG A. (1996), "Guest editor special issue on 'Regional and urban restructuring in Europe"”, European Urban \& Regional Studies, 3, 2,pp. 95-176.

MONTANARI A. (2012a), "Sustainable development in coastal urban areas. Multinational and multidisciplinary comparative projects, 1981-2011", in various authors, Exploring our Sustainable Future Socio-economic and Cultural Transfiguration and the Systemic Sustainability under the Globalization Dynamics : beyond 3.11., Hosei University Press, Tokyo, forthcoming.

MONTANARI A. (2012b), “Cross-national cooperation and human mobility : An introduction”, International Review of Sociology, forthcoming.

MONTANARI A., CURDES G., FORSYTH L.(eds.) (1993), Urban landscape dynamics. A multi-level innovation process, Aldershot, Avebury.

NIESSEN M. and PESCHAR J. (eds.) (1982), International Comparative Research. Problems of theory, methodology and organisation in Eastern and Western Europe, Oxford, Pergamon Press.

NIJKAMP P. (ed.) (1990), Sustainability of urban systems. A cross national evolutionary analysis of urban innovation, Aldershot, Avebury.

PETRELLA R. (ed.) (1971), Le développement régional en Europe, The Hague, Mouton.

PICKVANCE C.G. (2001), "Four varieties of comparative analysis", Journal of Housing and the Built Environment, 16, pp. 7-28.

PÖTZSCH R. and VOIGT F. (ed.) (1972), Le développement régional et les secteurs économiques, The Hague, Mouton.

ROBINSON E.A.G. (1969), "Introduction", in ROBINSON E.A.G. (ed.), Backward areas in advanced countries. Proceedings of a conference held the International Economics Association at Varenna, London, MacMillan, pp. ix-xviii.

ROBINSON E.A.G. (1969b), "Location theory, regional economics and backward areas", in ROBINSON E.A.G. (ed.), Backward areas in advanced countries. Proceedings of a conference held the International Economics Association at Varenna, London, Macmillan, pp. 3-20.

SCHAFF A. (1982), "Beschäftigung kontra Arbeit”, in FRIEDRICHS G., SCHAFF A. (eds.), Microelectronics and society : for better or for worse : a report to the Club of Rome, Oxford, Pergamon Press.

STROHMEIER K.P. and MATTHIESSEN C.W. (eds.) (1992), Innovation and urban population dynamics. A multi-level process, Aldershot, Avebury.

SZALAI A. (1977), "The organization and Execution of Cross-National Survey Research Projects", in SZALAI A., PETRELLA R., in collaboration with ROKKAN S., SCHEUCH E.K. (eds.), Cross-National Comparative Survey Research: Theory and Prectice, Oxford, Pergamon Press, pp. 49-93.

SZALAI A., PETRELLA R., ROKKAN S., SCHEUCH E.K. (1977), "Introduction”, in SZALAI A., PETRELLA R., in collaboration with ROKKAN S., SCHEUCH E.K. (eds.), Cross-National Comparative Survey Research: Theory and Prectice, Oxford, Pergamon Press, pp. vii-xviii. 
van der BERG L., DREWETT R., KLAASSEN L.H., ROSSI A., VIJVERBERG C.H.T. (1982), A Study of

Growth and Decline, Oxford, Pergamon Press.

von THÜNEN J.-H. (1966), The Isolated State, Oxford, Pergamon Press.

VILLAIN-GANDOSSI C. (1989), Project on the Final Act of Helsinki, Vienna Centre Newsletter, 35, pp. 50-52.

\section{NOTES}

1. The research leading to these results has received funding from the European Community's Seventh Framework Program FP7/2007-2013 under grant agreement nº 244251.

\section{ABSTRACTS}

In the aftermath of the Second World War, UNESCO sought to build peace in the world through the exchange of knowledge. To this end, it developed a number of initiatives to encourage international cooperation among social scientists. These initiatives were of particular importance in Europe, where there was a clear divide between Eastern and Western European countries. After the fall of the Berlin Wall, comparative research came to signify the transfer of knowledge and the promotion of innovation. Over the past two decades the study of urban phenomena, alongside social and economic issues, has taken on a strategic role in reducing pollution, safeguarding the environment and improving the quality of life of inhabitants. The process of enlarging the scope and objectives of policy has also led to a change in the role played by geography, which is increasingly required to offer instruments of scientific communication between the natural and social sciences.

Après la Seconde Guerre mondiale, l'UNESCO a tenté de construire la paix dans le monde à travers l'échange de savoirs. A cette fin, elle a mis sur pied un certain nombre d'initiatives visant à encourager la coopération scientifique. Celles-ci revêtaient une ampleur toute particulière en Europe, où existait un clivage net entre pays de l'Est et de l'Ouest. Suite à la chute du Mur de Berlin la recherche comparative signifia le transfert de savoirs et la promotion de l'innovation. Ces deux dernières décennies, l'étude des phénomènes urbains, de même que les questions sociales et économiques, ont pris un rôle stratégique par la réduction de la pollution, la sauvegarde de l'environnement et l'amélioration de la qualité de vie des habitants. Les processus d'élargissement du champ et des objectifs politiques ont également mené à une modification du rôle joué par la géographie, qui est de plus en plus sollicitée pour offrir des instruments de communication scientifique entre les sciences naturelles et sociales. 
INDEX

Mots-clés: recherche comparative, développement urbain, sciences sociales, géographie, projets transnationaux, projets multidisciplinaires, Adam Schaff

Keywords: comparative research, urban development, social sciences, geography, cross-national projects, multi-disciplinary projects, Adam Schaff

\section{AUTHOR}

\section{ARMANDO MONTANARI}

Department of European, American and Intercultural Studies, Sapienza University of Rome, armando.montanari@uniroma1.it 